University of Pennsylvania Carey Law School

Penn Law: Legal Scholarship Repository

Faculty Scholarship at Penn Law

$4-22-2020$

\title{
Lost in Transplantation: Modern Principles of Secured Transactions Law as Legal Transplants
}

Charles W. Mooney Jr.

University of Pennsylvania Carey Law School

Follow this and additional works at: https://scholarship.law.upenn.edu/faculty_scholarship

Part of the Banking and Finance Law Commons, Commercial Law Commons, Comparative and

Foreign Law Commons, Comparative Politics Commons, Finance Commons, Law and Economics

Commons, Legal History Commons, Political Economy Commons, Public Law and Legal Theory

Commons, and the Social and Cultural Anthropology Commons

\section{Repository Citation}

Mooney, Charles W. Jr., "Lost in Transplantation: Modern Principles of Secured Transactions Law as Legal Transplants" (2020). Faculty Scholarship at Penn Law. 2174.

https://scholarship.law.upenn.edu/faculty_scholarship/2174

This Article is brought to you for free and open access by Penn Law: Legal Scholarship Repository. It has been accepted for inclusion in Faculty Scholarship at Penn Law by an authorized administrator of Penn Law: Legal Scholarship Repository. For more information, please contact PennlawIR@law.upenn.edu. 


\title{
LostInTransplantationSSRNv1.docx
}

Not for citation, attribution, or quotation except

with the author's permission

\author{
LOST IN TRANSPLANTATION? \\ MODERN PRINCIPLES OF SECURED TRANSACTIONS LAW \\ AS LEGAL TRANSPLANTS
}

Charles W. Mooney, Jr.*

I INTRODUCTION AND BACKGROUND

II THE MODERN PRINCIPLES OF SECURED TRANSACTIONS LAW

III LEGAL TRANSPLANTATION: ALAN WATSON'S LEGAL

TRANSPLANTS AND ITS RELEVANCE FOR THE MODERN

PRINCIPLES

IV TRANSPLANTATION (OR NOT) OF THE MODERN PRINCIPLES IN CONTEXT

A Selected Challenges and Obstacles

i Impediments to Adoption of Modern Principles

a The 'Fallacy of Expertise'

b Legal Elites, Legal Culture, and Legal Concepts

c Missing Histories and Tilting at Windmills

d Opposition of Entrenched Interests

e Sui Generis, Fortuitous, and Hard-to-Classify

Factors

ii Impediments to Adoption of Modern Principles and Use of Secured Credit
a Governmental and Regulatory Influences
b Financing Patterns-E.g., Single, Dominant
Lenders versus Multiple Lenders
c Infrequency of Priority Conflicts
d Market Conditions
e Reliance on Immovable/Real Property

\footnotetext{
* Thanks to the University of Pennsylvania Law School and Gakushuin University Law School for generous support during the preparation of this article. Special thanks for helpful comments to Louise Gullifer and to the participants in the conference on 'Secured Transactions Law in Asia', sponsored by the National University of Singapore Faculty of Law and University of Oxford, Harris Manchester College, Commercial Law Centre, July 26-27, 2018, Singapore. Thanks as well for excellent research assistance to Olivia Daniels, University of Pennsylvania Law School, J.D. 2020.
} 


\author{
Collateral \\ iii Impediments to Use of Secured Credit (Under Current \\ Legal Systems and Assuming Adoption of Modern \\ Principles) \\ a Stigma and Reputational Concerns of Borrowers \\ b Valuation of Movables, Secondary Markets, and \\ Dispositions on Default: Chicken or Egg? \\ c Role of Insolvency Law and Proceedings: Use, \\ Abstinence, Treatment of Secured Claims, and \\ Impact on Secured Credit \\ d Costs of Use and Compliance, Including Complexity \\ B Selected Principles \\ i Comprehensive (Functional) Coverage of All Forms of \\ Security Rights. \\ ii Perfection by Registration and Priority Rules-in General \\ iii Registration (Notice Filing) and Creation: Collateral \\ Descriptions \\ iv Secured Creditor Restrictions \\ v Secured Debtor Restrictions. \\ vi Free Assignability and Anti-Assignment Clauses \\ vii Enforcement Following Default \\ C Some Watsonesque Perspectives \\ D Overcoming Obstacles \\ i Capacity Building \\ ii Incentives: Eg World Bank Doing Business Rankings \\ iii Promotion and Coordination \\ V BENEFITS OF MODERN PRINCIPLES: BEYOND CREDIT \\ ENHANCEMENT \\ VI CONCLUSION

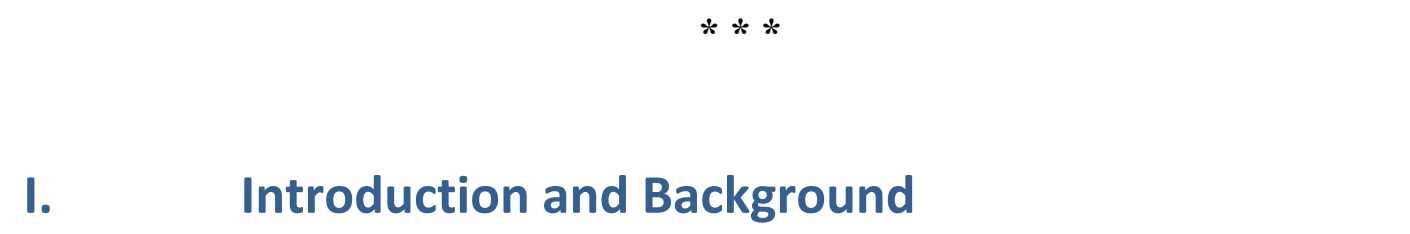

A global consensus has emerged as to a set of general principles to which secured transactions law for personal property should adhere. I refer to these as the Modern 
Principles of Secured Transactions Law (or Modern Principles). ${ }^{1}$ The sources of the Modern Principles include UCC Article $9^{2}$ and its many progeny, including the 2016 UNCITRAL Model Law on Secured Transactions ${ }^{3}$ (UNCITRAL Model Law) and its antecedent UNCITRAL texts. ${ }^{4}$ This chapter seeks to situate the Modern Principles into the more general sphere of the transplantation of law from one system to another. In particular, the chapter considers the adoption of the Modern Principles by States through the lens of the late Alan Watson's pathbreaking book, Legal Transplants. ${ }^{5}$ Insights provided by Legal Transplants and its various adherents and critics offer an interesting and useful heuristic for examining the legal transplantation of the Modern Principles. ${ }^{6}$

The process of enactment (or the failure to enact) Modern Principles-based laws plays a crucial role in transplantation. That process must negotiate various political obstacles and incentives, such as the positions of organizations and individuals with entrenched interests, governmental encouragement and discouragement, attitudes of legal elites, and sometimes the fortuitous intervention of particular individuals who champion (or oppose) the reforms. Moreover, an important focus for any analysis of transplantation of the Modern Principles is whether and to what extent laws embracing the Modern Principles, even if enacted, are actually used and accepted. The same factors that have an impact on the success or failure of the enactment process also may influence transplantation through the post-enactment use and acceptance of such laws.

In a recent article I advocate studies that would take 'a more systematic approach to the use - and memorialization in the literature - of experiences and lessons learned from work of individuals and organizations "on the ground" in the process of implementing [secured transactions law and insolvency law] reforms." 7 That article

\footnotetext{
${ }^{1}$ For an overview of the Modern Principles and their principal sources, see part II below.

${ }^{2}$ UCC Article 9 (Secured Transactions) (American Law Institute and Uniform Law Commission 2017).

${ }^{3}$ UNCITRAL Model Law on Secured Transactions (2016) (UNCITRAL Model Law).

http://www.uncitral.org/pdf/english/texts/security/ML_ST_E ebook.pdf.

${ }^{4}$ The Model Law was inspired by its predecessor, UNCITRAL Legislative Guide on Secured Transactions (2007), http://www.uncitral.org/pdf/english/texts/security-lg/e/09-82670_Ebook-Guide 09-0410English.pdf ('UNCITRAL Legislative Guide'). In July 2017 UNCITRAL approved the UNCITRAL Model Law on Secured Transactions Guide to Enactment, http://www.uncitral.org/pdf/english/texts/security/MLST_Guide to enactment_E.pdf ('UNCITRAL GTE').

${ }^{5}$ A Watson, Legal Transplants: An Approach to Comparative Law (Athens and London, University of Georgia Press, 1974, 2nd edn 1993).

${ }^{6}$ For an enlightening and important study that takes a different approach to the study of transplantation of the principles embedded in modern secured transactions laws, see RJ Wood, 'Identifying Borrowed Sources in Secured Transactions Law Reform' (unpublished manuscript on file with author). Wood undertakes to 'fingerprint' personal property security legislation in jurisdictions around the globe to determine 'the extent to which the jurisdiction has borrowed from each of . . three templates' - UCC Article 9, the Canada/New Zealand model, and the Model Law. Professor Wood's illuminating study will be a mandatory resource for the future examination and understanding of secured transactions law reforms. ${ }^{7}$ See CW Mooney Jr 'Insolvency Law as Credit Enhancement and Enforcement Mechanism: A Closer Look at Global Modernization of Secured Transactions Laws' (2018) 27 Norton Journal of Bankruptcy Law and Practice 673.
} 
reaffirms earlier work that articulated the significant impact of insolvency law on the behaviour of market participants outside actual or anticipated insolvency proceedings and the important role of insolvency law (and the actual use of insolvency proceedings in a given market) on the effectiveness of secured transactions laws. ${ }^{8}$ It also elaborates on the crucial importance of private international law rules (ie, choice-of-law rules) for secured transactions. And it argues that such rules are vital for the operation of secured transactions in the business credit markets and should be an integral part of the adoption and implementation of the Modern Principles.

While much of the discussion here may be applicable to consumer credit (ie, credit extended to natural persons for personal, family, or household purposes), the focus here is on the Modern Principles in the context of business credit. ${ }^{9}$ The studies that I propose derive from some hypotheses. One is that incorporation of the Modern Principles into a State's legal regime is a necessary—but not a sufficient — condition for a successful transplantation. Rephrasing this hypotheses in a more familiar vernacular: putting the Modern Principles 'on the books' will have little or no impact if the system is not actually used. Another is that successful transplantation of the Modern Principles into a given State's laws may depend on (sometimes sui generis) adaptations of and adjustments to the legal environment and business credit markets of the adopting State as well as modifications of the substance of the Modern Principles themselves.

The adoption of the Modern Principles need not be seen as an 'ultimate' goal. Rather, it is adequate access to credit that holds the most promise for enhancing social welfare. But access to credit does not necessarily depend on a market for secured credit (i.e., a market for credit which is conditional on the effective provision of collateral) or the adoption of the Modern Principles. So an important goal should be not merely the adoption of the Modern Principles but the development and support for a robust market for credit and an assessment of whether and how adoption of the Modern Principles can facilitate such a market. For example, if there exists a robust and accessible market for credit without collateral (or without the Modern Principles), then imposition of the Modern Principle legal regime may not have major, transformative effects on credit markets. On the other hand, adoption of Modern Principles-based laws may offer substantial benefits aside from such material market effects. ${ }^{10}$

These qualifications notwithstanding, the 'overall objective' of the Modern Principles, as reflected by the Model Law and related UNCITRAL texts, 'is to increase the availability and decrease the cost of credit by providing for an effective and efficient

\footnotetext{
${ }^{8} \mathrm{CW}$ Mooney Jr, 'Insolvency Law as Credit Enhancement: Insolvency-Related Provisions of the Cape Town Convention and the Aircraft Equipment Protocol' (2004) 13 International Insolvency Review, 27, 3439.

${ }^{9}$ As mentioned in ch 1, II, business credit is the focus of this book.

${ }^{10}$ See $\mathrm{V}$ below.
} 
secured transactions law.' ${ }^{11}$ The same can be said of the Cape Town Convention ('CTC') $)^{12}$ and its Protocols. ${ }^{13}$ Several studies and overwhelming empirical evidence confirm that the CTC and Aircraft Protocol have fulfilled this objective. ${ }^{14}$ While the Aircraft Protocol may be sui generis in its strikingly demonstrable effects, the adoption of the UNCITRAL texts and the ongoing Modern Principles-influenced global reforms demonstrate that at least an important segment of expert opinion subscribes to the general effectiveness of Modern Principles-based laws for these purposes. Consequently, this chapter proceeds on the general premise that adoption of the Modern Principles promotes social welfare as a general matter and is a worthy goal to be pursued. But the adoption of the Modern Principles does not necessarily contemplate the enactment of any particular statutory text - whether that might be based on Article 9, the Model Law, or any other model or template.

Following this Introduction, part II outlines the substance of the Modern Principles and their antecedents. Part III then summarizes relevant aspects of Watson's Legal Transplants and the positions of some significant adherents and critics of his theses and conclusions. It explains the potential relevance and utility of Watson's historical perspectives for the practical context of transplantation of the Modern Principles. With this background, part IV considers the transplantation of the Modern Principles from several of the most important perspectives, including the role of legal elites and legal culture, governmental and regulatory influences, opposition of entrenched interests, the role of insolvency law and proceedings, registration in public registries, descriptions of collateral in the context of registration and creation of security interests, and the market for business credit. In particular, it addresses various impediments to the adoption of the Modern Principles by States, obstacles to the use and acceptance of Modern Principles-

\footnotetext{
${ }^{11}$ UNCITRAL GTE II., para 4.

${ }^{12}$ Convention on International Interests in Mobile Equipment 2001, 2307 UNTS 285 ('CTC').

${ }^{13}$ Protocol to the Convention on International Interests in Mobile Equipment on Matters Specific to Aircraft Equipment 2001, 2367 UNTS 517 (Aircraft Protocol). Since entering into force on March1, 2006, the CTC and Aircraft Protocol have been adopted by 77 contracting States and one regional economic integration organization (European Union). UNIDROIT, Status of the Convention on International Interests in Mobile Equipment, http://www.unidroit.org/status-2001 capetown, accessed 5 Jan. 2018). The Protocols covering railway rolling stock and space assets are not yet in force. These are the Luxembourg Protocol to the Convention on International Interests in Mobile Equipment on Matters Specific to Railway Rolling Stock, 2007, 46 ILM 662; Protocol to the Convention on International Interests in Mobile Equipment on Matters Specific to Space Assets (adopted 9 March 2012). A fourth Protocol covering mining, agricultural, and construction equipment has recently been adopted (see https://macprotocol.info See UNIDROIT, Report (Nov. 2017), https://www.unidroit.org/english/documents/2017/study $72 \mathrm{k} / \mathrm{cge}$ 02/s72k-cge02-report-e.pdf; see eg R Goode, Official Commentary to the Convention on International Interests in Mobile Equipment and Protocol Thereto on Matters Specific to Aircraft Equipment, 2.1, at 13 (Rome: UNIDROIT, 3d edn 2013) ('A sound, internationally adopted legal regime for security, title-retention and leasing interests will encourage the provision of finance and leasing and reduce its cost.').

${ }^{14} \mathrm{CW}$ Mooney Jr, 'The Cape Town Convention's Improbable-but-Possible Progeny Part Two: Bilateral Investment Treaty-Like Enforcement Mechanism' (2015) 55 Virginia Journal of International Law 451, 454-58 (summarizing economic studies and CTC Discount, under which debtors located in CTC/Aircraft Protocol jurisdictions can receive substantial discounts on costs of financing).
} 
based laws in the markets for business credit, and hurdles for both adoption and use. Part $\mathrm{V}$ explains that the Modern Principles offer potential benefits other than the measurable expansion of access to credit and the lowering of the cost of credit, such as coherence, certainty, and ease of application and use. This is an important consideration that generally has been overlooked or underappreciated. Part VI then concludes the Chapter.

\section{The modern principles of secured transactions law}

The UNCITRAL Model Law epitomizes the Modern Principles. It is a relatively direct descendant of the Legislative Guide, ${ }^{15}$ UCC Article $9{ }^{16}$ and the various PPSAs adopted by Canadian Provinces. ${ }^{17}$ The Modern Principles are reflected as well in other model laws, ${ }^{18}$ in other secured transactions laws enacted by several States during recent years, ${ }^{19}$ and in laws that are currently being considered by other States. ${ }^{20}$ The Modern

\footnotetext{
${ }^{15}$ UNCITRAL Legislative Guide.

${ }^{16}$ By any measure UCC Article 9 has been an enormously successful legislative achievement. From its original promulgation in 1954 through several major revisions it has been adopted in all United States jurisdictions in substantially uniform fashion. Significantly, Article 9's principles have been emulated and adopted outside of the United States. This is evidenced by the influence of these principles on the laws actually adopted in other jurisdictions and on international harmonization efforts.

${ }^{17}$ See, e.g., Ontario Personal Property Security Act, R.S.O. 1990, c. P.10 (OPPSA).

${ }^{18}$ See, e.g., EBRD, Model Law on Secured Transactions (2004), http://www.ebrd.com/news/publications/guides/model-law-on-secured-transactions.html; Organization of American States, Model Inter-American Law on Secured Transactions, https://www.oas.org/dil/Model_Law_on_Secured_Transactions.pdf.

${ }^{19}$ E.g., Colombia, Ley No. $167 \overline{6}$ del 20 de Agosto de 2014, Por la Cual se Promueve el Acceso al Crédito y se Dictan Normas sobre Garantías Mobiliarias; See Mayer Brown, 'Colombia's New Law on Security Interest over Movable Assets Comes into Effect' (28 April 2014), https://www.mayerbrown.com/files/Publication/4868229b-de56-4b53-8669a55fcfdd728a/Presentation/PublicationAttachment/56e374b9-fab3-467f-b3b1aa1d67beafbb/Update_New_Regulations_Moveable_Assets_Colombia_0414.pdf; Jordan, Pakistan; E-Mail from Murat Sultanov, Secured Transactions Specialist, World Bank Group, to CW Mooney Jr (June 18, 2018, 03:01 EDT) (on file with author). In Africa, reforms that have taken place based completely, or near completely, on the Modern Principles include those in Kenya, Liberia, Malawi, Nigeria, Zambia, Rwanda and Zimbabwe. Reform which partially reflects the Modern Principles has taken place in Ghana, Sierra Leone, Burundi and Ethiopia, see M. Dubovec \& L. Gullifer, Secured Transactions Law Reform in Africa, ch. 2 (Hart 2019). In Asia, Brunei (ch 16) and the Philippines (ch 11) have introduced reforms based on the Modern Principles, while other reforms eg India (ch 18) partially reflect them (for analysis, see ch 18 (India) V.

${ }^{20}$ These states currently include, e.g., Bahrain, Bangladesh (see ch 17) Pakistan (see ch 19), Chile, Paraguay, Sri Lanka, St. Lucia, and Tunisia. E-Mail from Andres F. Martinez, Senior Financial Sector Specialist, World Bank Group, to CW Mooney Jr (July 1, 2017, 08:34 EDT) (on file with author); E-Mail from Murat Sultanov, Secured Transactions Specialist, World Bank Group, to CW Mooney Jr (July 1, 2017, 07:41 EDT) (on file with author); E-Mail from Murat Sultanov, Secured Transactions Specialist, World Bank Group, to CW Mooney Jr (June 18, 2018, 03:01 EDT) (on file with author).
} 
Principles also are embodied in the enormously successful CTC and Aircraft Protocol as well as the other CTC Protocols. ${ }^{21}$

There is no definitive or 'official' version of the Modern Principles. However, the Legislative Guide describes its "fundamental legal policies." 22 The EBRD and the WBG each has published their own synthesized and distilled versions as well. ${ }^{23}$ Based on the available statutory texts mentioned above as well as the Legislative Guide, WBG, and EBRD principles, I propose to include in the Modern Principles the following features: $:^{24}$

(i) public notice as a general condition for third-party effectiveness (perfection), including (x) a grantor identifier-based registry for registration of notices of security interests, and $(\mathrm{y})$ possession of tangible assets;

(ii) clear and easy to achieve methods for creation of security interests;

(iii) clear and predictable priority rules, including the general effectiveness of security interests in insolvency proceedings and priority of security interests over other interests;

(iv) provision for effective enforcement of security interests following a debtor's default, including extrajudicial enforcement;

(v) availability of all types of personal property as collateral, including future assets securing future obligations;

(vi) free assignability of receivables;

(vii) comprehensive coverage of all forms of security devices;

(viii) extension of security interests to the proceeds of collateral;

\footnotetext{
${ }^{21}$ Note, however, that although these instruments adopt an object-based registry rather than a grantor identifier-based registry, as contemplated by the Modern Principles. See eg CTC art. 18 (registration requirements).

${ }^{22}$ UNCITRAL Legislative Guide, 22-26.

${ }^{23}$ EBRD, 'Core Principles for a Secured Transactions Law', https://www.ebrd.com/what-we-do/legalreform/access-to-finance/transactions.html (EBRD Principles); WBG, 'Principles for Effective Insolvency and Creditor/Debtor Regimes', http://www.worldbank.org/en/topic/financialsector/brief/the-world-bankprinciples-for-effective-insolvency-and-creditor-rights (WBG Principles). Professor Wood also has summarized a set of 'operational principles' that 'provide the foundational building blocks' of secured transactions law reform. RJ Wood, $\mathrm{n}$ xr above, 7.

${ }^{24}$ All of these principles are discussed and explained in great detail elsewhere. See eg UNCITRAL Legislative Guide.
} 
(ix) the general acceptance of freedom of contract for inter-party relations;

(x) general equality of treatment of creditors providing acquisition financing;

(xi) clear private international law (choice-of-law) rules.

Other important principles embraced by the Model Law and other modern iterations of secured transactions laws are implicit in and follow as a part of the policy penumbra of these features. ${ }^{25}$

\section{Legal transplantation: Alan Watson's Legal Transplants and its relevance for the modern principles}

The analysis offered here draws on Watson's Legal Transplants not as a 'how to' for transplanting law - which certainly was not Watson's aspiration — but as a heuristic. The discussion aspires to offer a useful and accessible means of exploring legal transplantation in general and the transplantation of the Modern Principles in particular. Given this chapter's premise that the successful transplantation of the Modern Principles is on balance beneficial, Watson provides insights on both the practical and theoretical planes. It is important to bear in mind that a successful transplant would require not only the incorporation of the Modern Principles into the local law, typically by legislation, but the actual use and application of Modern Principles-based law in transactional settings. In particular, Watson's work provides some guidance for areas of inquiry in future investigations of law reform processes. Part IV considers these insights in addressing the challenges, successes, and failures of transplanting the most important elements of the Modern Principles.

Watson views comparative law as the "study of the relationship, above all the historical relationship, between legal systems or between rules of more than one system. ${ }^{, 26}$ But the primary focus here is not the dissection of the discipline of comparative law but rather the process of transplantation of law to (ie the borrowing of

\footnotetext{
${ }^{25}$ I have not proposed to include as Modern Principles increasing access to credit and lowering the cost of credit, although these are included in both the EBRD and WBG Principles. See EBRD Principle 1; WBG Principle A3. Although these goals and aspirations of the Modern Principles certainly are important, adoption of the Modern Principles is not the exclusive means for achieving them. Moreover, the Modern Principles may serve other purposes as well. See part V below. I propose to include in the Modern Principles only the relevant attributes of legal regimes. The UNCITRAL Legislative Guide observes this distinction between the objectives of a secured transactions regime and the legal policies designed to achieve them. See UNCITRAL Legislative Guide 22.

${ }^{26}$ Watson, Legal Transplants, 9.
} 
law by) a State. Watson analyzes the historical instances of legal transplants throughout the world, from ancient Near Eastern provisions regarding a goring ox ${ }^{27}$ to Roman law in Scotland ${ }^{28}$ and Holland ${ }^{29}$ to English law in New Zealand. ${ }^{30}$ Watson makes the case - and makes it convincingly - that transplanting individual rules of law or larger parts of legal systems is extremely common, and that most changes in legal systems are the result of borrowing. ${ }^{31}$

Watson contends that transplanting legal rules is socially easy-even with opposition from the legal establishment or the legislature. ${ }^{32}$ ' $[\mathrm{I}] \mathrm{t}$ remains true that legal rules move easily and are accepted into the system without too great difficulty ... even when the rules come from a very different kind of system.' ${ }^{33}$ He concludes that legal rules are not usually 'peculiarly devised for the particular society in which they ... operate and also that this is not a matter for great concern. ${ }^{34}$ Watson also emphasizes the overwhelming importance of authority for transplantation and for law generally. ${ }^{35}$ In examining a legal system's receipt of a transplant Watson encourages attention to how a system diverges from other, donor systems, not to the overall system, in order to determine what led a State to voluntarily seek and adopt the transplant. ${ }^{36}$ Significantly, Watson questions the extent to which adjustments made by recipient States actually conform law to fit their particular situations, arguing that the more important point is 'the psychological value of having [a State's] . . own legal system' ${ }^{37}$

It is not surprising that the book has been widely critiqued. Perhaps the most controversial aspects of Watson's theories are his conclusion that transplanting laws is socially easy and his failure to consider social variables surrounding legal transplants. ${ }^{38}$ Sir Otto Kahn-Freund in particular criticized Watson's lack of concern with the society that generated the transplanted law. ${ }^{39}$ By only presenting individual instances of legal

\footnotetext{
27 Ibid, 22.

28 Ibid, 44.

29 Ibid, 57.

30 Ibid, 74.

31 Ibid, 96.

32 Ibid, 95.

${ }^{33}$ Ibid, 95-96. He concludes that 'it would be a relatively easy task to frame a basic code of private law to operate throughout, with each nation being left free to modify for itself any part it found not to its liking.' Ibid, 100-01.

34 Ibid, 96.

${ }^{35}$ Ibid. In support, Watson argues that reception is possible and easy even when the receiving society is less materially and culturally advanced, and that foreign law may be influential even when 'totally misunderstood'. Ibid., 99.

${ }^{36}$ Ibid, 97.

${ }^{37}$ Ibid, 101.

${ }^{38}$ Ibid, discussing R Seidman, 'Book Review' (1975) 55 Boston University Law Review 682, $682-83$.

${ }^{39} \mathrm{O}$ Kahn-Freund, 'On Uses and Misuses of Comparative Law' (1974) 37 Modern Law Review 1. KahnFreund strongly disagreed with Watson's conclusions about the ease of transplanting laws, and claimed that borrowing law required understanding of the system from which the rules were being borrowed. Ibid; see J
} 
transplants into recipient countries, Watson may not have captured the full picture. ${ }^{40}$ But Watson emphasized that it was primarily the idea of a foreign law that is being transplanted. ${ }^{41}$ Many scholars agree that for a legal transplant to 'fit in' with the importing system, that system will need to be adaptive and receptive to different socioeconomic conditions, which requires taking notice of social, economic, and cultural conditions in both the importing and donating country. ${ }^{42}$

Criticisms notwithstanding, Legal Transplants continues to have 'legs' in the world of comparative law. Legal Transplants has been described as a 'landmark book' and a "'seminal" text' of comparative law. ${ }^{43}$ For example, Meryl Dean has drawn upon Watson's transplant theory but with refinements in her study of the jury trial in Japan. ${ }^{44}$ In another refinement, Hideki Kanda and Curtis Milhaupt, in their study of the transplantation of the corporate director's duty of loyalty from US law to Japanese law, argue that the success of a legal transplant turns on whether there is a "fit" between the imported rule and the host environment'. ${ }^{4}$

The goal here is not a critique of Watson's theory and methodology. It is instead the use of Legal Transplants as a heuristic and metaphor for assessing the transplantation

Cairns, 'Watson, Walton, and the History of Legal Transplants' (2013) 41 Georgia Journal of International and Comparative Law 637, 644-45.

${ }^{40}$ Watson, among other comparative law scholars, 'missed an equally important phenomenon - the impact of the process on the "donor" country.' F Foster, 'American Trust Law in a Chinese Mirror' (2010) 94 Minnesota Law Review 602, 607.

${ }^{41}$ Watson responded to Kahn-Freund:

What, in my opinion, the law reformer should be after in looking at foreign systems was an idea which could be transformed into part of the law of his country. For this a systematic knowledge of the law or political structure of the donor system was not necessary, though a law reformer with such knowledge would be more efficient. Successful borrowing could be achieved even when nothing was known of the political, social or economic context of the foreign law.

A Watson, 'Legal Transplants and Law Reform' (1976) 92 Law Quarterly Review 79.

${ }^{42} \mathrm{~W}$ Shi, 'Globalization and Indigenization: Legal Transplant of a Universal TRIPS Regime in a Multicultural World' (2010) 47 American Business Law Journal 455, 456. Inga Markovits has conceded that Watson is correct about the ease of legal transplants, but only in the case of self-executing law reforms that do not need popular approval or compliance to gain effect. I Markovits, 'Exporting Law Reform - But Will It Travel?' (2004) 37 Cornell International Law Journal 95, 98. Generally, however, in her view these are not the type of laws in question, and most legal reforms require cooperation from the citizenry and cultural harmony between the donor and recipient to become effective. Ibid, 99 .

${ }^{43}$ Cairns, 641-42.

${ }^{44}$ M Dean, 'Legal Transplants and Jury Trial in Japan' (2011) 31 Legal Studies 570.

${ }^{45} \mathrm{H}$ Kanda and C Milhaupt, 'Re-examining Legal Transplants: The Director's Fiduciary Duty in Japanese Corporate Law' (2004) 51 American Journal of Comparative Law 887, 891. The authors view 'success' in this context as the "use of the imported legal rule in the same way that it is used in the home country, subject to adaptations to local conditions.' Ibid, 890. '[F]ailure' in their view 'occurs when the imported rule is ignored by relevant actors in the host country, or the application and enforcement of the rule lead to unintended consequences.' Ibid. They explain: "'Fit" might be thought of as having two components-micro and macro. Micro-fit is how well the imported rule complements the preexisting legal infrastructure in the host country. Macro-fit is how well the imported rule complements the preexisting institutions of the political economy in the host country.' Ibid, 891. 
of the Modern Principles. For example, Watson compares law to technology, offering the wheel as a useful metaphor. ${ }^{46}$

\section{Transplantation (or not) of the modern principles in context}

It seems abundantly clear that the Modern Principles can be successfully transplanted. Adoptions in Canada and more recently in New Zealand and Australia, adoptions and introductions in other States, ${ }^{47}$ and the acceptance of the Modern Principles in various international harmonization projects (the UNCITRAL Legislative Guide and Model Law being the principle examples) and their ongoing influence on global reform efforts attest to this conclusion. But what of the situations in which the Modern Principles have not been successfully transplanted notwithstanding efforts to do so? And what of the situations in which substantial secured transactions law reforms have been made but which do not follow the Modern Principles? And what of the situations in which no meaningful attempts have been made to reform secured transactions law, much less to embrace the Modern Principles? This part explores some more and less successful aspects of the transplantation of the Modern Principles. In considering secured transactions law reforms it may be useful to imagine Watson's 'wheel' metaphor in considering whether the Modern Principles offer a 'fit' for a recipient (or would-be recipient) State and in the assessment of local adaptations. ${ }^{48}$ For example, did a State 'get' the 'idea' of the Modern Principles to be transplanted? And even if local adjustments are understandable from political and economic perspectives, are the local adjustments and the justifications for the adjustments coherent?

The discussion draws in part on the country-specific chapters in this volume. It also is inspired and informed in by an ongoing research project that I am currently undertaking with two Japanese scholars. ${ }^{49}$ The project consists of a qualitative empirical

\footnotetext{
46 Watson explained:

[L]aw like technology is very much the fruit of human experience. Just as very few people have thought of the wheel yet once invented its advantages can be seen and the wheel used by many, so important legal rules are invented by a few people or nations, and once invented their value can readily be appreciated, and the rules themselves adopted for the needs of many nations.

Watson, Legal Transplants, 100. It might be helpful to consider adaptations of the Modern Principles in light of examples of possible positive and negative adaptations of the wheel. Positive examples are: rubber tires (for smoothing out bumps), ball bearings (for relatively frictionless wheel rotation), and front-wheel steering mechanisms (for steering through easy, rounded turns). Negative adaptations might include: substitution of a flat, sleigh-like skid (fine perhaps for ice or snow, but difficult for sand, rocks, or other rough surfaces), square or octagon wheels (possible to rotate, but bumpy and requiring much more power than round versions, and a log- or tube-shaped single wheel instead of two opposite-side wheels (rotation is adequate but heavy and involves much friction).

${ }^{47}$ See $n n$ xr above.

${ }^{48}$ See text at note $\mathrm{xr}$ above.

${ }^{49}$ My co-investigators are Megumi Hara (Professor of Law, Gakushuin University Law School), and Kumiko Koens (Professor, Yamagata University Faculty of Literature and Social Sciences, Department of Public Policy and Social Studies).
} 
study of business credit in Japan - the Japanese Business Credit Project (or 'JBCP') involving interviews of representatives of Japanese financial institutions, governmental bodies, and businesses as well as legal professionals such as practitioners and academics. Our goal is an assessment of Japanese markets for private business credit, including the Japanese laws that govern secured transactions in tangible movables (such as a firm's inventory or business equipment) and claims (such as a firm's accounts receivable) to secure extensions of business credit. Among other aspects of the Japanese business credit market, the study investigates underlying causes of Japan's failure to embrace Modern Principles.

This chapter also draws insight from invitational conferences on the coordination of global reforms of secured transactions laws held in February 2017 and October 2018. ${ }^{50}$ Those conferences brought together individuals representing many of the most important organizations that work on reforms of secured transactions laws and insolvency laws. During the conferences several themes emerged. One overarching theme was that enactment by a State of statutory reforms is insufficient of itself for successful implementation of a modern secured transactions law. Another was that global reform efforts would benefit greatly from increased coordination among the various organizations involved with that work. Examples of coordination failures abounded.

Several problems associated with implementation of reforms were discussed. For example, some States have received conflicting advice and have enacted secured transactions laws that are not sufficiently compatible with newly adopted insolvency laws. Some advisors present States with very simple, streamlined versions of secured transactions laws that others consider hopelessly incomplete. Other advisors favour more complete statutory approaches that some consider unnecessarily complex.

A clear consensus emerged that an important but enormously challenging obstacle to reform is the need for capacity building - stimulation of the capacities of prospective debtors and creditors to usefully and profitably employ secured transactions law reforms. This would include steps such as consultations with and education of the various stakeholders affected by secured transactions laws as well as cultural shifts in relevant attitudes and social norms. ${ }^{51}$ Of course, the foregoing offers only a taste of the discussions. But a common thread appears to be that capacity building in various forms, including fundamental and structural changes in characteristics of credit markets and

\footnotetext{
${ }^{50}$ The 2017 Coordination Conference was held on February 9-10, 2017, at the University of Pennsylvania Law School, Philadelphia, PA. It was co-sponsored by the International Insolvency Institute (III), the National Law Center for Inter-American Free Trade (now, Kozolchyk National Law Center (NatLaw)), and the Organization for the Harmonization of Business Law in Africa. The 2018 Coordination Conference was held in Madrid, October 16-17, 2018, co-sponsored by the III, NatLaw, and Universidad Carlos III de Madrid.

${ }^{51}$ See eg N Cohen, 'Capacity Building as a Key Determinant of Success in Secured Transactions Reform', http://www.uncitral.org/pdf/english/colloquia/4thSecTrans/Presentations/2ContGonST2/COHEN_Colloqui um Presentation.pdf.
} 
cultural and legal traditions and norms, are necessary conditions for successful implementation of modern secured transactions laws. Enactment of statutory text, alone, often may be a necessary but insufficient step.

One theme of this chapter is to advocate for further and more rigorous empirical studies of secured transactions laws reforms. It makes no claim to have developed a definitive set of conclusions about the transplantation of the Modern Principles. But it does aspire instead to offer some useful guidance for the development of further investigation. The following discussion in Subpart A addresses several challenges and obstacles to transplantation of law in general and of the Modern Principles in particular. These are impediments to the adoption of the Modern principles, to their effective use and implementation even if adopted, or to both their adoption and use. Subpart B then turns to several components of the Modern Principles. It addresses the impact and role of the various obstacles to transplantation on these aspects of the Modern Principles.

Drawing on part III, Subpart C offers a 'Watsonesque' perspective on transplantation of the Modern Principles.

\section{A. Selected Challenges and Obstacles}

i. Impediments to Adoption of Modern Principles

a) The Fallacy of Expertise

Before focusing on a taxonomy of more specific obstacles to the adoption of the Modern Principles and causes of relevant adjustments and deviations, it is useful to reflect on an overarching impediment. I refer to this factor as the 'Fallacy of Expertise'. It is based on an aggregation of anecdotal observations and experiences over several decades of involvement with commercial law reform efforts. It may be stated as a simple syllogism relating to a proposal for a reform of legal rules from the perspective of a person (below, 'I') occupying a position of formal or informal influence and whose views are respected in the law reform process:

(i) I exercise my expertise competently to recognize the need to improve the law and to propose any beneficial law reforms.

(ii) I did not think of the proposed law reform.

(iii) Therefore, the proposed law reform is not a good idea and should not be adopted.

The problem with this silly little syllogism, of course, is that its first predicate incorporates the term 'competently' - not 'perfectly'. It is all too rare an event for a relevant expert to respond to a proposal — no matter how sound — with something like: 'By golly, why didn't I think of that? What a great idea!' Of course, no one actually 'admits' reliance on the Fallacy. Moreover, I have no doubt that the Fallacy may be most 
influential on the behaviour of those who have no subjective consciousness of its operation and who, in the utmost good faith, rely on 'objective' and 'rational' argumentation, reasoning, and evidence. ${ }^{52}$ But most readers will easily recognize the Fallacy when they see it and appreciate its operative role in the process.

\section{b) Legal Elites, Legal Culture and Legal Concepts}

In the realm of 'technical' aspects of private law doctrine — of which the Modern Principles would generally be considered a part—experts among the legal elites often are the most influential advisors and actors. This is understandable and, in many respects, is a good thing. Experts among the legal elites (experienced and successful practitioners and respected academics and judges) play an important role in adapting the prevailing 'legal culture' and 'legal concepts' to reforms such as the Modern Principles and in making appropriate adjustments to those principles as well as reciprocal adjustments to the local legal culture and concepts. Certainly such adaptations and adjustments may be beneficial and important conditions for successful transplantation. And, as a practical (read: political) matter, support or opposition from the legal community may be the most important box to tick in the reform process. But this necessarily means that the legal establishment also may be the most significant obstacle to reform. ${ }^{53}$

The role of the Fallacy of Expertise and the success or failure of resisting its influence may be most obvious and significant among the legal elites. Legal establishments in general appear to harbour great scepticism of changes perceived to be fundamental, ${ }^{54}$ especially if advanced by 'external' sources. ${ }^{55}$ Reforms such as the Modern Principles are agnostic inasmuch as they tend to conflict with both civil and

\footnotetext{
${ }^{52}$ For example, consider Eric Berne's metaphor in the context of script analysis of human behaviour: ' $[\mathrm{M}]$ ost people spend their time sitting in front of a player piano going like this with their fingers and saying, "How do you like the music I am making?", under the delusion that they are making the music.' E Berne, 'Transcription of Eric Berne in Vienna, 1968 IV International Congress of Group Psychotherapy' (1973) III Transactional Analysis Journal 63, 68. The Fallacy sometimes may be a manifestation of the Dunning-Kruger effect: '[W]hen people are incompetent in the strategies they adopt to achieve success and satisfaction, they suffer a dual burden: Not only do they reach erroneous conclusions and make unfortunate choices, but their incompetence robs them of the ability to realize it.' J Kruger and D Dunning, 'Unskilled and Unaware of It: How Difficulties in Recognizing One's Own Incompetence Lead to Inflated SelfAssessments' (1999) 77 Journal of Personality and Social Psychology 1121.

${ }^{53}$ See ch 8 (China) IVA and V (discussing resistance to revision of Civil Code and conservative attitude of civil law scholars and drafters); ch 14 (Thailand) IV B and V B. [23, 32-33] (discussing resistance to revision of Civil Code and Commercial Code); ch 13 (Taiwan) III B (conflicts with civil law traditions hinders reforms). On the other hand, the need for more flexible systems of secured transactions has led to judicially sanctioned systems of title transfer security in Japan and South Korea. See ch 10 (Japan) III A (ii) (discussing jōto tanpo title transfer security); ch 12 (South Korea) II B (discussing yangdodambo title transfer security).

${ }^{54}$ See ibid.

${ }^{55}$ See ch 14 (Thailand)VA (discussing view that compliance with international standards is not an adequate basis for reform).
} 
common law doctrines and traditions. ${ }^{56}$ However, legal elites in some jurisdictions are less accustomed than others to evaluating legal doctrine in terms of standards as specific as economic efficiency or as general as social welfare. The 'ought' may be too often gleaned from the 'is'. 'Reasons' for resistance to reforms may be repeated over and over with little rigorous analysis or debate, forming a difficult-to-penetrate-and-rebut conventional wisdom. ${ }^{57}$ Moreover, the intensive study and analysis of legal doctrinewhether in the civil or common law contexts - does not necessarily illuminate or lead to understanding of the operation of markets for business credit and the potential economic effects of reforms such as the Modern Principles.

The role of legal elites is, understandably and appropriately, most pronounced in their defense of (and resistance to modifications of) the local legal culture, and especially in relation to significant imbedded legal concepts. Inasmuch as security rights as contemplated by the Modern Principles are proprietary ('property' or 'real' rights), doctrinal legal concepts such as the roles of 'title' are particularly resilient. ${ }^{58}$ These concepts may collide head-on with the Modern Principles in the process of transplantation (or not).

There are other bases for scepticism of positions taken by legal elites toward law reform proposals. Practitioners and academics alike may have incentives to resist change. Practitioners, for example, may benefit professionally (preserving esteem and positions of respect- 'psychic income') and financially from opposing reform and preserving the status quo. ${ }^{59}$ Imagine a secured transactions 'regime' that consists of a complex web of esoteric and highly conceptual doctrinal meanderings, pock-marked with forks in the road, detours, and barricades, the corpus of which is comprehensible only with the 'benefit' of circuitous and detail-laden (even pretentious) intellectual histories, which are often imbedded in lengthy reported judicial decisions that somehow manage to reach some results (notwithstanding internal inconsistencies and considerable indeterminacy) while reflecting little consensus. ${ }^{60}$ Such a regime may enshrine the demand for legal advice at every turn. It would not be a mere coincidence that legal elites in a jurisdiction whose law might be so described would be quite resistant to efforts to adopt the Modern Principles, which would devalue their hard-earned knowledge and experience even though it would create net benefits for the society in general.

\footnotetext{
${ }^{56}$ See ch 7 (reform in civil law jurisdictions) and ch 16 (reform in common law jurisdictions)

${ }^{57}$ Consider reasons proffered for retaining existing systems under Singapore law, such as changes would require a "complete overhaul" and current law has "worked well." See ch 20 (Singapore) , [19, 23].

${ }^{58}$ See ch 14 (Thailand) IVB and VB(i) (discussing the determination of third-party effects and strict standards of identification for property to be transferred) and IV B i, ii, and iii below.

${ }^{59}$ This account would be consistent, for example, with the persistence of the complex amalgam of common-law and statutory rules for secured transactions laws in Singapore. See ch 20 (Singapore) part IV] (outlining a trenchant critique of current law while concluding that major changes are unlikely). Compare the relative success of the reform in Pakistan and the proposed reform efforts in Bangladesh in an environment of similar English and common-law traditions. See ch 19 (Pakistan) and ch 17 (Bangldesh). ${ }^{60}$ The style and structure of this sentence seeks to exemplify the point.
} 
Compare that scenario to the actual experience with the development of Article 9 in the US. I will be among the first to concede, lament, and assume part of the blame for the statute having grown to be far too complex and detailed. But, ultimately, between the statutory text and the official commentary, it does provide accessible and relatively certain and reliable answers and guidance. But the point to be made here relates to the role and approach of the legal elites. The organized bar, the various other law-reform oriented organizations, and the individual legal experts that have played a significant role in the development and advancement of Article 9 have consistently sought to foster a legal regime that provides clear results, a unitary approach to security devices, and simplified notice filing, while encouraging the use by the business community of standard forms without the need for day-to-day legal intervention. Whether they succeeded perfectly is beside the point. The relevant legal elites sought to reduce the roles of legal experts in the operation, application, and understanding of secured credit transactions. ${ }^{61}$

Putting aside the self-interest of legal elites, their roles in the law reform process also may reflect the interests of their clients. Of course, their clients are entitled to legal representation in advocating for their interests in the legislative and related processes. But the matter addressed here is the role of the legal elites who purport to be advocating for the public interest in their roles as legal experts. What actually amounts to client advocacy might be mistaken - and sometimes may be intended to be so mistaken - for neutral and objective 'expert' opinions. Perhaps even more insidious, legal elites may seek to protect their own professional and financial interests by claiming that they are advocating for a particular interest group, such as unsecured trade creditors.

\section{c) Missing Histories and Tilting at Windmills}

Advocating for a change in law and offering a critique of current law often may be hindered by an inadequate record supporting the adoption of current law and past (and ongoing) rejection of reforms. Flaws in the relevant reasoning and erroneous factual premises are difficult or impossible to assess and criticize in the absence of reliable records of the bases for past decisions and current positions of lawmakers. And rebuttals of the bases for decisions suffer when the relevant evidence is anecdotal and suspect and the attribution to lawmakers is unproven. One of the beauties of the harmonization process within international organizations (and the uniform law process in the United States) is the availability of reliable evidence of the debates, assumptions, reasoning, and

\footnotetext{
${ }^{61}$ I readily confess to some bias in the assessment. This experience with legal elites in the Article 9 context offers a stark contrast to the attitudes and behavior of the bar in the United States that specializes in real estate law. In general the real estate bar tends to be absorbed with retaining state-by-state idiosyncratic discrepancies in doctrine and practice and, consequently, has been resistant to harmonization efforts.
} 
decisions. These inadequacies have been a recurring problem in our investigations on the JBCP.

\section{d) Opposition of Entrenched Interests}

As with any proposal for a change in law, opposition to adoption of the Modern Principles can be expected from those whose interests align with retaining current law. ${ }^{62}$ For example, the Modern Principles might be thought to encourage competition from foreign financers and non-bank lenders who might rely on secured lending to compete with local banks, whose 'knowledge of the territory' affords a competitive advantage in making unsecured loans. Such local lenders with entrenched market positions may also be concerned about the Modern Principles' facilitation of the creation and perfection of senior security interests in favour of other, potentially competing lenders. Similarly, sellers and other financers of movables that rely on title reservation transactions, which are effective under existing local law without registration, also may resist and oppose the unified, functional approaches to security rights under which such title-based structures would be made effective against third parties only by registration. The general point here is that financial market participants may view existing legal infrastructures as advantageous and legacy financers with substantial market shares under existing legal regimes may be reluctant to embrace change - even if adoption of the Modern Principles would benefit borrowers and the local economy more generally. ${ }^{63}$

In some cases the outcome determinative factors in the law reform process may be difficult to characterize, random, or wholly fortuitous. While the concerns addressed here are the impediments to law reforms, obviously such factors also may support the adoption of reforms as well. One or more particularly influential individuals or organizations may take a strong position for or against reforms, which may or may not be based on sound policy arguments. ${ }^{64}$ Those advocating for changes in law would be well advised to be alert to these influences.

\footnotetext{
${ }^{62}$ See eg ch 14 Thailand IV B (i) (discussing opposition of banks to secured transactions reforms).

${ }^{63}$ Entrenched interests also may advocate for retention or adoption of provisions that would inhibit the use of secured credit, such as restrictions on the persons entitled to be secured creditors and restrictions on assignments of receivables. See IIIBiv and vi below.

${ }^{64}$ I would note, by way of example, my own role in the development of law in the United States concerning intermediated securities. See CW Mooney Jr, 'The Roles of Individuals in UCC Reform: Is The Uniform Law Process a Potted Plant? The Case of Revised UCC Article 8' (2002) 27 Oklahoma City University Law Review 553. Note also the role of David Allan in championing the Australian secured transactions law reform, see D. Brown, 'Australian Secured Transactions Law Reform' in L. Gullifer and O. Akseli (eds), Secured Transactions Law Reform: Principles, Policy and Practice (Hart Publishing, Oxford and Oregon 2016) 146-7.
} 


\section{ii. Impediments to adoption of Modern Principles and use of Secured Credit}

Some factors may present obstacles to formal adoption of the Modern Principles and also may inhibit the extension of secured credit even after enactment of Modern Principlesbased laws.

\section{a) Governmental and Regulatory Influences}

Governmental policies toward credit may have substantial negative (or positive) influences on the adoption of legislation incorporating the Modern Principles and on the extension of secured credit. Prudential regulation of banks that allows a haircut on reserve requirements for secured loans is a prime example. ${ }^{65}$ In many jurisdictions the unavailability of such favourable treatment for loans secured by movables and receivables - which effectively treats such loans the same as unsecured loans for this purpose-imposes an obstacle to the adoption of the Modern Principles by denying these regulatory incentives. That treatment also discourages the extension of secured credit, whether or not such reform legislation has been enacted. ${ }^{66}$

Governmental programmes that support small businesses through loan guarantees also may lessen the motivation that might otherwise exist to reform secured transactions law by reducing incentives and to extend secured credit. The reduction of credit risk under such loan guarantee programmes diminishes the benefits to a creditor of taking collateral, especially if the credit risk can be reduced through loan guarantees at a lower cost than extending secured credit. ${ }^{67}$

On the other hand, adoption of the Modern Principles actually could enhance and complement these guarantee programmes. To the extent that the guaranteed loans would require security through the operation of Modern Principles-based laws, losses arising out of borrower defaults - and the costs of such guarantee programmes - could be reduced. The guarantor could reduce or eliminate its losses to the extent that effective resort to the collateral were available. Moreover, lenders would build capacity through their experiences of extending secured (and guaranteed) loans.

Governmental attitudes toward protections for consumers and natural persons more generally also may influence the use of secured credit. An example is a restriction

\footnotetext{
${ }^{65}$ See eg G Castellano and M Dubovec, 'Bridging the Gap: The Regulatory Dimension of Secured Transactions Law Reforms' (2017) 22 Uniform Law Review 663.

${ }^{66}$ Other regulatory treatment also may reduce incentives to take collateral. For example, generous treatment with respect to the classification of bank loans as non-performing loans may reduce a bank's motivation to treat a loan as in default and to commence enforcement steps. See T Hoshi, 'The Hidden Risks in Japan's Financial System' (Dec. 2011) National Institute for Research Advancement, http://www.nira.or.jp/pdf/e_opinion4.pdf.

${ }^{67}$ See eg ch 10 (Japan) II; ch 13 (Taiwan) III B(discussing government supported guarantees).
} 
on persons that are eligible to become a debtor or grantor under a secured transactions law or a law applicable to registration of security rights. ${ }^{68}$

\section{b) Financing Patterns-E.g., Single, Dominant Lenders versus Multiple Lenders}

The first-to-register priority rule and the efficacy of broad collateral descriptions (e.g., 'all inventory now owned or hereafter acquired by grantor') permitted by the Modern Principles makes it possible for a single secured creditor to 'lock in' a priority position. This aspect of the Modern Principles regime might cause resistance to its adoption by a jurisdiction in which it is customary for a business borrower to maintain relationships with several lenders of funds. But resistance on that basis would be unjustified. Multiple lenders of funds who might otherwise have equally ranking unsecured claims against a common debtor could, under an inter-creditor agreement, easily share in collateral as secured creditors under a first-to register priority scheme. ${ }^{69}$ The purchase money security interest exception to the 'first to file' priority rule ${ }^{70}$ also facilitates diversity of financiers, since an acquisition financier can obtain limited superpriority without an inter-creditor priority agreement. Adoption of the Modern Principles need not necessarily lead to the prevalence of a single, dominant secured lender to a borrower.

\section{c) Infrequency of Priority Conflicts}

In some jurisdictions priority conflicts - such as those involving a grantor's wrongful creation of security rights in favor or more than one creditor - may be relatively rare. $^{71}$ This might result from - and reflect - the ethical norms that prevail in the local legal and business cultures. Such circumstances might support the view that a registration system providing for public notice of security rights and a corresponding first-to-register priority rule are not needed. But the relative paucity of outright fraud does not demonstrate that a registration-priority system that provides certainty is not worthwhile and should be rejected. This is especially so if the relevant market lacks a Modern Principles-based secured transactions legal regime and is one in which secured credit does not play a prominent role. Although adoption of the Modern Principles in that

\footnotetext{
${ }^{68}$ See IIIBv below.

${ }^{69}$ For example, the creditors all could be named as secured creditors in the registration or an agent could be named as the secured creditor to hold collateral on behalf of all of the creditors.

${ }^{70}$ See ch 3 II A (iii) for a brief account of the purchase money security interest rule. See also ch 4 VII.

${ }^{71}$ See for example, City of London Law Society, Financial Law Committee, Commentary to Draft Secured Transactions Code page 97, at http://www.citysolicitors.org.uk/storage/2016/07/Draft-Secured-TransactionCode-Commentary-Discussion-draft-July-2016.pdf.
} 
jurisdiction might not 'revolutionize' the credit markets, that would not of itself justify clinging to a creaky and complicated legal infrastructure that is otherwise problematic and that imposes unnecessary costs on the extension of secured business credit. ${ }^{72}$

\section{d) Market conditions}

Recall that the principal goals of a secured transactions law incorporating the Modern Principles are the increased availability and reduced costs of credit. ${ }^{73}$ In a market in which the cost of credit is extremely low and unsecured credit is perceived to be readily available, at first blush adopting the Modern Principles might offer little practical appeal. If the expenses attendant to providing collateral are perceived to be significant, such a change in law would be that much less attractive. And for small loans to SME borrowers, such expenses would cause adoption of the Modern Principles to seem even less appealing. But, of course, a low-interest-rate environment may not always remain such. Moreover, even under such market conditions there presumably would always be some subset of borrowers and situations in which personal property collateral would be necessary or beneficial. Those borrowers and lenders could benefit greatly from laws that follow the Modern Principles.

\section{e) Reliance on Immovable/Real Property collateral}

In a jurisdiction in which business loans typically are unsecured or collateralized by immovable (real) property, the impact of this circumstance on prospects for adopting the Modern Principles and for increased reliance on personal property collateral is similar to that of the low-cost, high-accessibility-of-credit market just described. As explained there, however, adoption of the Modern Principles nonetheless could be a beneficial step for such a jurisdiction. iii. Impediments to the use of Secured Credit (under current legal systems
and assuming adoption of Modern Principles)

The foregoing discussion considered some circumstances that may discourage extensions of secured credit even under a prevailing Modern Principles-based legal regime. This discussion addresses additional impediments to the use of secured credit.

\footnotetext{
${ }^{72}$ See $\mathrm{V}$ below.

${ }^{73}$ See I above.
} 


\section{a) Stigma and reputational concerns of borrowers}

In some jurisdictions there is a prevailing belief or assumption that obtaining credit secured by personal property creates a stigma; casting doubt on the financial stability of a borrower. ${ }^{74}$ It sometimes is observed that granting personal property collateral signals a 'last resort' for a financially troubled borrower. Doubtless there is some truth to these characterizations in jurisdictions in which observations confirm this correlation in fact. Although troubled firms sometimes (or often) provide personal property collateral, it does not follow that a firm that provides such collateral in fact is financially distressed. At the margin, however, this potential stigma plausibly could dissuade a borrower from obtaining much needed credit if it were conditioned on providing personal property collateral. Further study might shed light on the extent to which this 'stigma' concern merely reflects some vague sense of malaise perpetuated through repetition or actually is a material impediment to obtaining credit.

\section{b) Valuation of Movables, Secondary Markets, and Dispositions on Default: Chicken or Egg?}

Underlying the economic potential of the Modern Principles is the core idea that the value of collateral could be effectively applied toward satisfaction of a secured obligation upon a debtor's default. Lenders in some markets harbour substantial uncertainty about this key assumption, in particular with respect to movables collateral. For example, some bank lenders report that they lack (in-house) expertise for valuing movables and that, in any case, a thin secondary market for such collateral makes recoveries on default uncertain. ${ }^{75}$ Some of these lenders have no actual experience with enforcing security rights in movables following a default.

It is unsurprising that there would not be a robust secondary market for movables collateral following debtor defaults in jurisdiction in which loans secured by movables are, relatively speaking, infrequently made. That is to say, a thin market may reflect, at least in material part, a thin market for movables-secured loans - thus presenting the 'chicken or egg' conundrum.

\footnotetext{
${ }^{74}$ See ch 10 (Japan) VIII B (ii) (in relation to asset-based lending).

${ }^{75}$ See ch 10 (Japan) VIII A
} 
In a real sense the 'acid test' of security rights is the effectiveness of those rights in a debtor's insolvency proceedings. ${ }^{76}$ As a practical matter such effectiveness may be the most important context of perfection (third-party effectiveness) of a security right. But the impact of insolvency effectiveness generally on security rights and of the details of the treatment of security rights in insolvency proceedings may extend beyond the actual treatment of actual security rights in actual insolvency proceedings. The potential treatment serves to bolster the credit enhancing attributes of security rights by increasing the availability and lowering the costs of credit — precisely the principal goals of the Modern Principles. ${ }^{77}$

The treatment of security rights in insolvency proceedings may serve as an effective means of de facto enforcement. Viewed ex ante, this perception supports the credit enhancement function of security rights and encourages extensions of secured credit. For example, in the US financially distressed firms often are the subjects of Chapter 11 reorganization proceedings. Secured claims generally are honoured ${ }^{78}$ and secured creditors may proceed with relative confidence that their collateral will be accounted for and dealt with in a value-enhancing manner. Collateral might be sold in a sale of substantially all of a debtor's assets as a going business. The insolvency proceeding provides a forum and mechanism for the valuation and orderly treatment of secured claims. Secured creditors expect collateral to be available, under court supervision, and subject to rules designed to protect collateral value. In a jurisdiction in which resort to insolvency proceedings is not the norm for a financially distressed business debtor, considerable uncertainty may exist as to the prospective treatment of a secured creditor's collateral following a debtor's financial demise. ${ }^{79}$ When insolvency proceedings are the norm for business financial distress orderly dispositions may contribute to the development or maintenance of a robust secondary market for movables. In contrast to the situation in the US, this seems to be the case in Japan, where the incidence of formal insolvency proceedings for distressed debtors is quite small by

\footnotetext{
${ }^{76}$ See ch 5 .

${ }^{77}$ See UNCITRAL GTE, quoted at fn 11 above; Mooney, 'Enforcement', fn 14 above; Mooney, 'Credit

Enhancement', fn 7 above.

${ }^{78}$ Secured claims might be honored and respected in a variety of ways, such as by disclaimer or abandonment of collateral to permit enforcement by a creditor outside of an insolvency proceeding, supervised disposition of collateral in an insolvency proceeding, or valuation of collateral and a distribution of value under a plan of reorganization.

${ }^{79}$ See part IV A iii above (discussing valuation, secondary markets, and dispositions on default).
} 
comparison. ${ }^{80}$ A robust market for disposition in insolvency proceedings may, in turn, benefit enforcement through dispositions of collateral outside of insolvency proceedings.

Finally, this discussion of insolvency law might well have been included under part IV A ii above, ${ }^{81}$ inasmuch as the insolvency law and related practices in a State also may represent an impediment to the State's adoption of the Modern Principles. For example, the 'strong' version of security rights under the Modern Principles might be of concern if the State's insolvency law and practice were such that the combination of the two regimes would erect obstacles to rescue and rehabilitation of distressed debtors. The more appropriate response to that situation would be to combine the adoption of a Modern Principles-based secured transactions law with adjustments in the State's insolvency laws so as to be more compatible with rehabilitation. ${ }^{82}$

\section{d) Costs of use and compliance, including complexity}

Extensions of secured credit will be discouraged by a legal regime for secured transactions that is complex, expensive, and difficult to use. ${ }^{83}$ Examples of such obstacles are formalities such as collateral description requirements that are complex and require assistance by legal professionals for perfection and priority of security rights, a public registry that is inconvenient to access and imposes substantial fees for registrations, and regulatory constraints that result in significant expenses for valuations of collateral. Such flaws in the legal and regulatory infrastructure would be substantially ameliorated by the adoption of Modern Principles-based secured transactions laws.

\section{B.Selected Principles}

\footnotetext{
${ }^{80}$ During the January-September 2018 period the number of court filings of business insolvency proceedings in Japan (an average of 685 filings per month) were about $9.13 \%$ of the number of filings in the United States (an average of 7,495 per month). Trading Economics, Japan Bankruptcies, https://tradingeconomics.com/japan/bankruptcies; Trading Economics, United States Bankruptcies, https://tradingeconomics.com/united-states/bankruptcies. Compare the relative size of each country's GDP for 2017, which (in billions of United States \$) was 19,390.604 for the United States and \$4,872.137 for Japan (about $25.1 \%$ of the United States GDP). The World Bank, GDP, Current US, https://data.worldbank.org/indicator/NY.GDP.MKTP.CD?locations=US.

${ }^{81}$ Impediments to adoption of Modern Principles and use of Secured Credit.

82 [Possible $\mathrm{xx}$ to ch 5.]

${ }^{83}$ See ch 9 (Indonesia) III B (authorities' formalistic approach and lack of clarity hinders use of current law), III D (iii) (use of notaries and formalities such as listing values and obligations causes confusion and unnecessary expense); See ch 12 South Korea IV (discussing complexities and costs of registration system including requirement that both parties apply, examination by registrar, and registration requirement upon creation, extinguishment, and other events).
} 
This subpart considers several of the Modern Principles as compared to the corresponding treatment (or lack of treatment) under secured transactions laws that persist unreformed or that have been adopted by selected States. It considers the impact on these principles of the various challenges and obstacles to transplantation discussed in Subpart A.

\section{i. Comprehensive (functional) coverage of all forms of security rights}

The Modern Principles embrace a 'functional, integrated and comprehensive regime' for security rights. ${ }^{84}$ It follows that under the Modern Principles devices such as the retention of title by a seller and a transfer of title by a debtor to a creditor to secure an obligation are treated as security rights. As such, they are subject to the other dimensions of the Modern Principles such as the requirements for creation and perfection and priority rules, discussed next. It is unsurprising that this clash between substance and economic reality, as embraced by the Modern Principles, and entrenched form- and label-based characterizations would trigger shock and resistance from local interests, including legal elites. ${ }^{85}$ Legal experts are unlikely to enjoy seeing expertise developed over years of experience rendered obsolete (although change also may present new opportunities for the more ambitious and opportunistic). But legal regimes should not exist and persist for the enjoyment and prosperity of legal elites.

Adoption of a functional, comprehensive regime for security rights also may attract opposition from those whose practices and business models would be adversely affected or, at least, inconvenienced (in particular by the imposition of a requirement for perfection by registration). ${ }^{86}$

\section{ii. Perfection by Registration and Priority Rules - in general}

The most instrumental of the Modern Principles are the provision for registration in a public registry as the principal method of achieving third-party effectiveness (i.e., perfection) and the corresponding first-to-register priority rule. These rules directly confront — and would override — parallel rules typically found in both civil law and common law traditions. For example, pledges of movables typically have required a delivery and assignments of money claims (receivables) generally have required

\footnotetext{
${ }^{84}$ UNCITRAL Legislative Guide, 57; see UNCITRAL Model Law, Arts. 1(1) (application of Model Law to security rights); 2(kk)(i) (definition of 'security right').

${ }^{85}$ See ch 14 (Thailand) IV B (i) and (ii) (discussing lack of understanding of why the failure to have an integrated system is problematic).

${ }^{86}$ See part IV B (ii) below.
} 
notification to or an acknowledgment by the underlying obligor or other action with respect to the obligor ${ }^{87}$

Adoption of a system for public registration of transfers (or notices of transfers) for security as a method of third-party effectiveness is a good first step. But that move would not alone meet the registration and priority standards contemplated by the Modern Principles. For example, if the pre-existing methods of perfection (such as a notification to or acknowledgement by an obligor on receivables) that do not require delivery of actual possession or some other form of public notice are left intact and remain available, and if (under a first-in-time of transfer principle) an earlier transfer made effective under those methods takes priority over a transfer that is later registered, then the registration system falls short of the requirements of the Modern Principles. Under such a structure, for example, a transferee who conducted a search of the registry and found no conflicting registration nonetheless would find its interest subordinated to an earlier-in-time ('secret') unregistered interest. Such a registration and priority regime fails to satisfy the essential purpose of the perfection and priority rules embodied in the Modern Principles. Yet some states, including Japan and Korea, have quite consciously and purposefully adopted such a regime. ${ }^{88}$ That adaptation aptly fits the 'square wheel' paradigm.

Such a square wheel might be characterized as a 'compromise' between transplanting the Modern Principles (round wheel) and respect for and reliance solely on traditional methods of effective transfers (skids). To be sure, it is an improvement. This registration alternative, for example, would allow a transferee of a large number of receivables to ensure third-party effectiveness (in particular in the transferor's insolvency proceeding) without the expense and delay of dealing with multiple obligors. The approach also appeases the interests of those parties who wish to achieve third-party effectiveness while avoiding the expense of dealing with the registration system. Moreover, it may not deviate materially from the Modern Principles in practice. For example, as discussed above, ${ }^{89}$ in a given market priority conflicts arising out of a transferor's 'double assignment' or 'double financing' may be so rare that adopting a first-to-register priority rule would not produce material adverse effects. Similarly, the adoption of square wheels (or no wheels) on a tiny island where walking is the principal means of transport may not present a serious practical problem. Stated otherwise, in some cases the adoption of an absurd rule would do little damage. Even so, it would remain an absurd rule.

\footnotetext{
${ }^{87}$ Although, under the common law, an assignment of receivables is valid even if the debtor is not notified, see ch 16 IV B.

${ }^{88}$ This generally describes the situation under Japanese and Korean law. See ch 10 (Japan) V; ch 12 (South Korea) III C (ii). See also Chapter 18 (India) IV F.

${ }^{89}$ See IV A (ii) (c) above.
} 


\section{iii. Registration (Notice Filing) and Creation: collateral descriptions}

Another pillar of the Modern Principles is the 'notice filing' aspect of a registration system. The information to be contained in the registration notice need contain only the basic information concerning a security right sufficient to put a searcher on notice that the secured creditor may have a security right in the relevant asset. In particular, the reference to the collateral in a notice need not be a detailed and specific. As provided in the registry provisions of the Model Law, '[a] description that indicates that the encumbered assets consist of all of the grantor's movable assets, or of all of the grantor's movable assets within a generic category' is adequate. ${ }^{90}$ So, for example, a reference to 'all inventory now owned or hereafter acquired by grantor' would be adequate. Such a general description also would be sufficient in a security agreement for purposes of creating a security right under the Model Law. ${ }^{91}$

This approach has been rejected by secured transactions legislation in some jurisdictions. ${ }^{92}$ In the case of Japan, one reason given for this rejection is curious. Requiring more specific descriptions for creation and registration of security rights by way of title transfers (jöto tanpo) is seen as a protection from so-called 'overcollateralization'. ${ }^{93}$ For registration of assignments of movables and claims, in order for an assignment to cover future, after-acquired property effectively, it is necessary to provide specificity such as by identifying the location of movables or the source of claims. ${ }^{94}$ Adoption of a standard permitting such broad descriptions would (the argument goes) facilitate the security transfer to a creditor of substantially all of a grantor's assets. A specificity requirement makes such broad coverage more difficult (but presumably still possible) to achieve. If virtually all of the assets of a grantor were covered by a security transfer, and if the obligation secured were relatively small compared to the value of the collateral, then the excess value of those assets would be essentially unavailable for use as collateral to secure credit from other creditors. ${ }^{95}$ Alternatively, if no such disparity between a secured obligation and collateral value exists, then it is argued that in some cases there might be virtually no free assets available for satisfaction of claims of other creditors in the case of the grantor's insolvency.

Arguably implicit in this specificity requirement is the assumption that permitting an easily achieved broad coverage for a security transfer that could make the excess value

\footnotetext{
${ }^{90}$ UNCITRAL Model Law, Model Registry Provisions, Art 11.

${ }^{91}$ UNCITRAL Model Law Art 9(2).

${ }^{92} \mathrm{See}$, in relation to Japan, Act on Special Provisions, etc. of the Civil Code Concerning the Perfection Requirements for the Assignment of Movables and Claims, Law No. 104 of 1998, as amended and renamed by Law No. 148 of 2004 ('PRAMC'); ch 10 (Japan) VI.

${ }^{93}$ See ch 7, III D and ch 10 (Japan) VI C

${ }^{94} \mathrm{Ch} 10$ (Japan) VI. In many cases it is necessary for a creditor to retain a judicial scrivener in order to ensure satisfaction of the description requirements, especially for future (after-acquired) assets.

${ }^{95}$ This is so in part because of the relatively weak position of junior creditors under the prevailing title transfer security arrangements in Japan.
} 
so unavailable would not be in a grantor's interest. But why should it be assumed that a market failure exists or would exist that would lead a grantor to agree to such a security arrangement that would not be in its interest? Similarly, why should it be assumed that it is necessary to restrict party autonomy by making it more expensive and cumbersome for a grantor to transfer interests in its property as it may choose? Concrete evidence of the reasoning behind the specificity requirement, including answers to the questions just posed, would provide a useful baseline for advancing the debate. ${ }^{96}$

\section{iv. Secured creditor restrictions}

An example of an entrenched interest opposition to the Modern Principles may be the adoption or retention of restrictions on the persons eligible to be a secured creditor and to hold security rights. Such restrictions could inhibit the use of a secured transactions law, even if it embraced the Modern Principles. Restricting the persons eligible to receive and hold security rights to entities with market power or that otherwise benefit from extending credit without relying on modern secured transactions laws could have adverse economic consequences. Such restrictions could constrain (or fail to expand) the availability of credit or increase (or fail to reduce) the cost of credit. However, a State may have legitimate interests in regulating and licensing persons engaged in the extension of credit to the public. Whether such limitations on holding security rights are unwise efforts to protect entrenched interests and market positions ${ }^{97}$ or legitimate exercises of regulatory power would depend on the relevant facts. If the former, then such restrictions would implicitly contradict the underlying goals of the Modern Principles.

For example, limiting the extension of secured credit to bank lenders - i.e., deposit-taking institutions - would presumably fall outside of the legitimate regulation of the extensions of credit. Whether or not a lender is also licensed as a bank (i.e., to take deposits) would not seem to have any bearing on protecting the public in the context of commercial loans. ${ }^{98}$ But legislation enacted in Thailand is not so restrictive. It limits the use of its secured transactions law to secured creditors that are 'financial institution[s]' or other persons or entities specified by ministerial regulations. ${ }^{99}$ But for present purposes

\footnotetext{
${ }^{96}$ See IV A(i)(c) above (discussing difficulties in rebutting arguments in favor of statutory treatment in the absence of authoritative evidence of reasoning and policies responsible for its adoption).

${ }^{97}$ See IV A (i)(d) above (discussing opposition to reforms by entrenched interests).

${ }^{98}$ If under a State's regulatory structure only banks are licensed to make commercial loans, that might suggest the need for the State to provide for the licensing and regulation of non-bank lenders as a means of increasing the availability of business credit.

${ }^{99}$ Business Security Act, Sec. 7. 'Financial institution' refers to a financial institution according to the law governing financial institution business, a life-insurance or non-life insurance company, and a bank or a financial institution established under any specific law. Ibid, Sec. 3. Under the Ministerial Regulation on
} 
the relevant point is that what might appear to be the exercise of legitimate regulation and supervision by a State might actually amount to the preservation of entrenched market positions that impedes the goals of the Modern Principles.

\section{v. Secured debtor restrictions}

As discussed above, governmental approaches toward consumer and other natural person debtors may result in restrictions on the types of persons that could be debtors under the relevant secured transactions laws. ${ }^{100}$ As in the case of restricting eligible secured creditors, this could implicitly contradict the underlying goals of the Modern Principles to increase access to credit. ${ }^{101}$ Japan's PRAMC provides for the use of the registration system for the perfection of assignments of title of movables and claims only for assignments made by 'juridical persons'. ${ }^{102}$ This relegates assignments by natural persons to reliance on traditional Civil Code methods of third party effectiveness. Many SMEs in Japan and, presumably, in other jurisdictions are owned and operated by natural persons as sole proprietorships and not as companies or other legal entities. It follows that such restrictions that limit access to the use of secured transactions laws are likely also to limit access to credit, to increase the cost of credit, or both. ${ }^{103}$

\section{vi. Free assignability and anti-assignment clauses}

Specifying the Types of Lender, the secured party may be a juristic person having the objective to involve in securitization, a trustee of a trust under the law governing trust for transactions in capital market, a securities firm, a mutual fund, a bondholders' representative under the law governing securities and exchange, a juristic person operating a derivatives business, an asset management company, and a juristic person having the objective to conduct factoring business. Business Security Act, B.E.2558, B.E.2559 (2016). Moreover, under the Ministerial Regulation on Specifying the Types of Lender under the Business Security Act No.2, B.E.2561 (2018), the secured creditor under the Business Security Act B.E. 2558 may be the Office of the Permanent Secretary of the Industry Ministry dealing with the SMEs Civil Development Fund, a foreign commercial bank dealing with syndicated loans, a juristic person having the objective to involve in hire-purchase or leasing transactions, and a juristic person having the objective to involve in financing transactions. See ch 14 (Thailand) IV B (i). A similar system applies in India (see ch 18 IV A). The Pakistan reformed law is limited in scope to financial institutions or a consortium of financial institutions, as defined in the Financial Institutions (Recovery of Finance) Ordinance, 2001, and does not, therefore, apply to supplier finance.

${ }^{100}$ See eg ch 8 (China) II A (discussion applicability of 2007 law for use by only certain debtors, resulting in fragmented system); the common law system which applied in Brunei before reform (ch 16 II B); IV A (ii)(a) above (discussing governmental and regulatory influences).

101 See IV B (iv) above.

102 PRAMC, Art. 1 (providing provisions for 'perfection requirements for the assignment of movables and claims conducted by juridical persons.' A ‘juridical person' under Japanese law includes a company organized under the Companies Act. Companies Act, Act No. 86 of July 26, 2005, Arts. 2(i) (defining 'Company'); 3 (company is a juridical person).

${ }^{103}$ Note that the UNCITRAL Model Law preserves the protections of parties to transactions for 'personal, family or household purposes' under other laws, but does not otherwise contemplate limiting its use by natural persons as debtors or grantors (art 1(5) 
Another manifestation of entrenched interest resistance to the Modern Principles is the retention of the legal effectiveness of an agreement between an obligor and an obligee on a money claim (receivable) that an assignment by the obligee is not effective. ${ }^{104}$ Major companies may have sufficient bargaining power to insist that such provisions are included in their supply contracts (as obligors), which relieves them of any responsibility to deal with assignees. ${ }^{105}$ On the other hand, one might think that bank lenders, who might be interested as prospective assignees, would support the free assignability in accordance with the Modern Principles. But it also is plausible that some lenders might oppose free assignability out of concern that their borrowers might otherwise be more likely to assign receivables to other creditors. These lenders presumably would be motivated by an interest in preserving their market positions. Notwithstanding these potential concerns, Japan recently modified its law to provide that such anti-assignment clauses are ineffective to prevent a valid and enforceable assignment. ${ }^{106}$ However, such anti-assignment provisions remain effective as between the parties, to the end that an assignment would constitute a breach of contract by the assignor. Thus, a significant disincentive remains to assignments of receivables subject to such anti-assignment provisions.

\section{vii. Enforcement following default}

The powers typically associated with 'title' or 'ownership' of property lend themselves quite comfortably with the exercise of default remedies in secured transactions. This may explain in part some States' incentives to retain title-based secured transactions and to resist the comprehensive, functional scope of the Modern Principles. This may be further encouraged by what are perceived as cumbersome procedural requirements for exercise of remedies under statutory schemes for pledges and mortgages. But the Modern Principles embrace robust rights of enforcement. There is no principled reason why resort to a title-based device necessarily would offer stronger remedies (although a creditor's having 'title' may retain a strong intuitive appeal). On the other hand, if the motivation for retaining title-based devices is to insulate a secured creditor from reasonable procedures to preserve any surplus value of collateral (i.e., in

\footnotetext{
${ }^{104}$ In Pakistan, inclusion in the Financial Institutions (Secured Transactions) Act 2016 of a provision overriding anti-assignment clauses was rejected on the grounds of interference with freedom of contract, see ch 19 (Pakistan) IV F.

${ }^{105}$ The policy underlying the free assignability of receivables recognizes that the benefits of facilitating such assignments drastically outweigh any risks and burdens of obligors.

${ }^{106}$ Law No. 44 of 2017 (effective April 1, 2020). The new rule will apply to pre-existing contracts. See ch 10 (Japan) IV B (iii).
} 
excess of the secured obligation) for the benefit of the debtor, the Modern Principles simply reject that approach as incoherent and penal. ${ }^{107}$

\section{Some Watsonesque perspectives}

The Modern Principles can be transplanted and received well by States that reflect a range of attributes, thus supporting the idea that they are eminently transplantable. But questions remain as to the circumstances under which transplantation fails or is seriously incomplete or deviant. Watson's Legal Transplants may offer some useful insights as to appropriate areas of investigation and research. In this respect it supports the thesis of this chapter that further understanding of law reform processes in general and in particular those dealing with secured transactions laws would benefit greatly from more rigorous empirical studies. Our current work on the JBCP follows this path and we hope that it will be an exemplar for similar investigations.

The experience with transplantation of the Modern Principles provides some support for Watson's claim that transplantation of legal rules may be 'socially easy'. ${ }^{108}$ This is reflected by their assimilation into a variety of legal cultures and societies. But the deviations from the Modern Principles that States have made also evidence Watson's appreciation that States make reforms to borrowed laws in the transplantation process. This preliminary examination of the transplantation of the Modern Principles may cast some doubt, at least in the present context, on Watson's claim that adjustments do not conform the States' particular circumstances (depending, admittedly, on what one considers to be relevant particular circumstances). At least in this context of modern commercial law, the dominant influences of legal elites (broadly including not only the professionals but the legal culture and doctrinal and conceptual influences) and the political power of entrenched interests do appear to take account of a State's specific situations. But these adjustments to local circumstances (or selective rejections of the Modern Principles) are not necessarily socially beneficial, especially when these two important influences converge.

Japan's 'square wheel' adaptation of the registration and priority aspects of the Modern Principles reflects a failure even to incorporate the basic 'idea', much less the details, of a first-to-register priority rule. ${ }^{109}$ But it may well reflect only a 'split the difference' compromise among various competing local interests—including legal

\footnotetext{
${ }^{107}$ Of course, a title-based security device need not run afoul of such debtor protections. For example, the judicially approved title-transfer security device in Japan (jöto tanpo) recognizes a debtor's entitlement to the surplus value and even recognizes the possibility of creating junior title-transfer security rights. See ch 10 (Japan) III A (ii)(a).

${ }^{108}$ See III above.

${ }^{109}$ See IV B (ii) above.
} 
elites - which a political process failed to resolve in a principled way. Similarly, efforts of commercial lenders to protect entrenched market positions, such as resistance to the effectiveness of anti-assignment provisions, also may reflect an adaptation to the particulars of local circumstances. ${ }^{110}$ But those 'particulars' might be nothing more that the protection of a dominant market position. That is not necessarily a 'cultural adjustment' worthy of our applause and respect.

Perhaps Watson's most compelling claim is that virtually all law is borrowed. Yet one might quite plausibly wonder, for example, how the rather complete reception by Holland of Roman law by the 17th century may be relevant to the transplantation of the Modern Principles in the 21st century. ${ }^{111}$ On the other hand, Watson's explanation of the more or less fortuitous borrowing of Ulrich Huber's teachings on conflict of laws in the early development of laws in the United States seems no less apt when considering transplantation of the Modern Principles. ${ }^{12}$ This borrowing appears to have resulted primarily from the availability of the source and not from any similarity or other affinity between the donor(s) and the recipient. ${ }^{113}$

The borrowing phenomenon invites some interesting reflections on the development of the Modern Principles, and in particular the development of UCC Article 9. To be sure, UCC Article 9 borrowed from ideas developed in the United States and elsewhere concerning secured commercial financing transactions. But it also offered a new, sui generis and holistic approach that has inspired and found its way into the Modern Principles and into the laws of numerous States. UCC Article 9 fundamentally rejected common law ideas about nonpossessory security. It addressed concerns about fraud (and to a lesser extent, ostensible ownership) by offering as an antidote a simple notice-filing system for public notice. It rejected the 'principle' that still prevails in some common-law jurisdictions that even if a transaction walks like a duck, quacks like a duck, and looks like a duck, it is a chicken if the parties so name it-e.g., title reservation transactions. ${ }^{114}$

A relatively small group of scholars and practitioners bore the responsibility, and deserves the credit, for the successful emergence of UCC Article 9. It was necessary (not only for Article 9 but for the development of the UCC as a whole) to overcome

\footnotetext{
${ }^{110}$ See IV B (vi) above.

111 Watson, Legal Transplants, 57.

112 Ibid, 109-110. Watson described how early law in the United States borrowed Huber's axioms from England, which was influenced by the high regard for Huber in Scotland (through the influence of Lord Mansfield, a Scot), which in turn had been influenced by Dutch law. As Watson explained:

What most concerns us here is that, on an issue so vital to the well-being of the United States and its citizens, there was for so long no societal input into the basic principles, and even the judges, as subordinate lawmakers, gave credence to particular foreign authority with no apparent interest in alternative approaches.
}

Ibid. 109.

${ }^{113}$ Ibid.

${ }^{114}$ See ch 16 IV C. 
substantial opposition from powerful circles. ${ }^{115}$ These efforts benefited from the prevailing uniform law process in the United States, which removed the project from the usual political environment of the legislative processes. Alas, that is a luxury that is not available in most States.

\section{Overcoming Obstacles}

The foregoing discussion of challenges and obstacles to the adoption of Modern Principles and the use of secured credit also provides a roadmap of sorts for steps and strategies for overcoming or reducing these impediments. This subpart identifies examples of positive approaches for overcoming obstacles and advancing the adoption and use.

\section{i. Capacity Building}

The need for capacity building was an important theme that emerged from the coordination conferences. ${ }^{116}$ Efforts directed to developing debtor and creditor capacities to understand and utilize secured transactions could meaningfully address many of the challenges to the adoption of the Modern Principles as well as the effective extensions of secured credit. ${ }^{117}$ For example, a widespread appreciation of the benefits of secured credit could reduce or eliminate the stigma sometimes associated with security. ${ }^{118}$ Similarly, education and training of credit personnel and the development of secondary markets for movables could address valuation problems that inhibit the development of secured credit markets. ${ }^{119}$

\footnotetext{
${ }^{115}$ Consider the comments of Professor Grant Gilmore, during the review of the UCC by the New York Law Revision Commission, at a public hearing:

The memoranda read this morning on behalf of the New York Clearing House ... were so riddled with mistakes, inaccuracies, misreadings and misconstructions as to be largely untrustworthy and as to throw grave doubt on the professional competence in this field of those who prepared the memoranda. It cannot be overlooked that these memoranda were submitted to this Commission by representatives of some of the largest banks in New York City, advised presumably by competent counsel. These are harsh words, deliberately chosen, which I shall be prepared to document before you gentlemen tomorrow.

2 New York Law Revision Commission, Hearings on the Uniform Commercial Code 1161 (1954).

${ }^{116}$ See IV above.

${ }^{117}$ See, for example, ch 9 (Indonesia) III A (many stakeholders still do not fully understand 1999 law so 'implementation is patchy and rife with issues'); ch 12 (South Korea) V (ineffectiveness of current secured transactions law resulting from business parties' unfamiliarity with law, lack of movables valuation techniques and data on valuation, and paucity of expertise on management and maintenance of collateral); Ch 14 (Thailand) IV B (i) and (ii) (failure to understand need for an integrated system for secured transactions); ch 15 Vietnam IV (International Finance Corporation work with Viet Nam Banks' Association on capacity building for banking sector)..

${ }^{118}$ See IV A (iii)(a) above.

${ }^{119}$ See IV A (iii) (b) above.
} 


\section{ii. Incentives eg World Bank 'Doing Business' rankings}

The economic benefits that may result from a State's adoption of a Modern Principles-based secured transactions law provide tangible incentives for reform. Another, less tangible but important, incentive may arise from a State's desire to improve a its rankings in the World Bank's annual Doing Business report. ${ }^{120}$ In the context of secured transactions law reforms the rankings on the strength of legal rights in connection with getting credit are particularly significant. ${ }^{121}$ While these rankings have been subjected to considerable (and well-deserved) criticism, ${ }^{122}$ it is clear enough that improving a State's ranking has provided a meaningful incentive for reform. ${ }^{123}$

\section{iii. Promotion and coordination}

Finally, the past and ongoing work of the many organizations and individuals in the implementation of secured transactions law reforms deserve much credit for the progress to date. Many of these were represented at the 2017 and 2018 coordination conferences. ${ }^{124}$ One hopes that the current efforts to provide enhanced coordination of these efforts will provide even more success in the future.

\section{Benefits of Modern Principles: beyond credit enhancement}

The potential benefits of adopting the Modern Principles extend beyond the prospects for increasing access to and lowering the cost of credit. Indeed, in some markets prevailing conditions, such as exceedingly low interest rates and the prevalence, convenience, and financial rewards of government-sponsored guarantees, might substantially blunt those credit enhancement attributes of a Modern Principles-based secured transactions law.

\footnotetext{
${ }^{120}$ For the most recent report, see World Bank Group, Doing Business 2019 (16th edn), http://www.worldbank.org/content/dam/doingBusiness/media/Annual-Reports/English/DB2019report_web-version.pdf.

${ }^{121}$ See ibid, 95 ('The strength of legal rights index measures the degree to which collateral and bankruptcy laws protect the rights of borrowers and lenders and thus facilitate lending ... .'). For the rankings in the 2019 report (based on May 1, 2018 data), see World Bank Group, Rankings and Ease of Doing Business Score, http://www.doingbusiness.org/en/rankings.

${ }^{122}$ See eg Oakland Institute, It is Time to End the Business Rankings of the World Bank (Jan. 26, 2018), https://www.oaklandinstitute.org/it-time-end-business-rankings-world-bank.

${ }^{123}$ As reported by the WBG, 'Since its launch in 2003, Doing Business has inspired more than 3,500 reforms in the 10 areas of business regulation measured by the report.' Doing Business 2019, fn 121 above, vi; see also eg ch 13 (Taiwan) I, III A and B, IV A (iii) (discussing influence of WBG Doing Business Survey); ch 14 (Thailand) I, V A (same); ch 16 II A (Brunei's secured transactions law reforms were intended to move Brunei up the Doing Business rankings and, indeed, achieved that goal).

${ }^{124}$ See IV above
} 
But even in the absence of any demonstrable and measurable macroeconomic impact of credit enhancement, there is much to commend the adoption of such reforms.

A Modern Principles-based law offers many laudable attributes-coherence, relative simplicity, certainty, transparency, and user-friendliness. This is especially so when compared to the balkanized taxonomies of security devices under both commonlaw and civil-law traditions. These attributes reflected by the Modern Principles typically are central aspirations of law reform. Yet these advantages appear to occupy a reduced and subservient status when compared to the more visible and frequently touted goal of economic growth through enhanced access to and lower costs of credit. It is of course quite appropriate to recognize and advocate for the potential economic gains from a Modern Principles-based legal regime. But viewing such law reforms solely from that perspective holds secured transactions law reforms to an unreasonable, indeed unfair, standard.

\section{Conclusion}

Further investigation of transplantation processes for secured transactions laws (including the Modern Principles) may well reveal the weakness, even incoherence, of arguments supporting the status quo and in opposition to (or favoring deviation from) the Modern Principles. This exposure may overcome resistance that otherwise would be successful absent careful public scrutiny. The harmonization processes within UNCITRAL, UNIDROIT, and other organizations that have produced the Modern Principles provide some powerful evidence for this prospect. To be sure, the same counter-arguments made (and that continue to be made) in the local law reform processes were heard throughout the harmonization and modernization efforts on the international level. Open discussion and frank debates exposed, rebutted, and overcame weak and incoherent positions. ${ }^{125}$

Maybe - just maybe - reforms of secured transactions laws in some States that reject one of more of the most fundamental of the Modern Principles are appropriate adjustments that will, on balance, promote social welfare. Further investigation and research concerning secured transactions law reforms should, of course, be open to this prospect. But I am profoundly sceptical. It is likely that the arguments that proved to be losers in the work on international harmonization and modernization of secured transactions laws are losers still. As we ponder arguments supporting the need for adjustments and deviations from the Modern Principles to accommodate the asserted needs, culture, and particular circumstances of a State considering reforms, we should be

\footnotetext{
${ }^{125}$ A technical term used by some political scientists and others for such poor argumentation and reasoning, described by Merriam-Webster as 'usually vulgar', is 'bullshit' (defined as 'nonsense; especially: foolish insolent talk'). Merriam-Webster.com. Merriam-Webster, n.d. Web. 13 July 2018.
} 
mindful of the idea underlying the Modern Principles. The international harmonization effort reached a consensus that the current laws of many States are inferior, ineffective, and inefficient and should be replaced. Secured transactions laws, like laws in general, are not created equal. Some work better than others.

But this scepticism about significant deviations from the Modern Principles also should be tempered in at least two important respects. First, 'second best' approach adopted by a State as a political compromise may nonetheless reflect a substantial improvement over the legal regime that it replaces. And progress sometimes-often I would think - proceeds only incrementally and along a winding path. Perhaps the most important conclusion from Watson's insights, although not unique, is that the law is perpetually in a state of flux. ${ }^{126}$

Second, these principles - while here bestowed with the appellation "modern"are (conservatively) more that 65 years old. ${ }^{127}$ They have seemingly been stubbornly immune to evolution or modification of a fundamental nature. Even recently emerged significant artifacts of the Modern Principles - the Guide on the Implementation of a Security Rights Registry ${ }^{128}$ and the UNCITRAL Model Law-appear to be oblivious to the emerging Fintech ${ }^{129}$ advances, other than embracing 20th century legacy technology for registries. ${ }^{130}$ But one hopes that the energy and imagination that infused the processes that developed and implemented the Modern Principles will emerge and inspire further evolution and adjustments to these principles. Recent publications that address registries offer some encouragement in this respect. ${ }^{131}$

\footnotetext{
${ }^{126}$ See eg Watson, Legal Transplants, 96 (transplantation is extremely common; most changes in legal systems result from borrowing).

${ }^{127}$ This dates the Modern Principles (perhaps arbitrarily, but not unreasonably) from the 1952 Official Text of the UCC.

${ }^{128}$ UNCITRAL, Guide on the Implementation of a Security Rights Registry (2013) (Registry Guide), https://uncitral.un.org/sites/uncitral.un.org/files/media-documents/uncitral/en/security-rights-registry-guidee.pdf

${ }^{129}$ See G Walker, 'Financial Technology Law-A New Beginning And A New Future' (2017) 50 The International Lawyer 137:

FinTech has emerged as a powerful new market force as a result of the coming together of a number of disconnected trends. Significant advances have occurred in the areas of computer and digital technology, the Internet, mobile telecommunications as well as economics and finance, which have transformed traditional areas of study and created important potential new business structures and operations.

${ }^{130}$ Registry Guide, fn 130 above, 31-33.

${ }^{131}$ See eg CW Mooney Jr, 'Fintech and Secured Transactions Systems of the Future' (2018) 81 Law and Contemporary Problems 1; T Rodríguez de las Heras Ballell, 'Digital Technology-Based Solutions for Enhanced Effectiveness of Secured Transactions Law: The Road To Perfection?' (2018) 81 Law and Contemporary Problems 21; see also CG Bradley, 'Disrupting Secured Transactions' Houston Law Review (forthcoming), https://papers.ssrn.com/sol3/papers.cfm?abstract_id=3275263.
} 